\title{
The treason of the clerks
}

\section{Conor Cruise O’Brien}

Academic Freedom and Apartheid: The Story of the World Archaeological Congress. By Peter Ucko. Duckworth, London: 1987. Pp.305. Hbk £18; pbk $£ 9.95$.

Peter Ucko is Professor of Archaeology at Southampton University and was appointed National Secretary of the British Congress of the International Union of Pre- and Protohistoric Sciences (IUPPS). The Congress was due to be held at Southampton in September 1986. In September 1985, however, the British Executive, without consultation with the IUPPS, decided to ban the participation of South African scholars. In January 1986, the International Executive Committee of the IUPPS declared that it "cannot accept any meeting where participation is subjected to non-scientific considerations as being organized under the auspices of the Union. Therefore the Executive Committee refuses to recognize the Southampton meeting as the IUPPS Congress". The British National Committee went ahead with the Southampton conference, while continuing to describe it as the "World Archaeological Conference". The XIth IUPPS Congress, originally scheduled for Southampton, was instead held at Mainz in September of this year.

The transactions discussed in Academic Freedom and Apartheid had no effect whatever on apartheid, as far as I know. But they did have a significant and negative effect on respect for academic freedom, and therefore on academic freedom itself, both in Britain and in South Africa, and to some extent elsewhere. The events that led up to the Southampton Congress, and the split in the IUPPS, therefore form a not insignificant chapter in the intellectual history of the late twentieth century.

As British National Secretary, Professor Ucko was at the centre of these events. The publication of his book about them is therefore to be welcomed, though it should be taken with more than one grain of salt. It is, perhaps inevitably, a strongly partisan account. Even Neal Ascherson, in a distressingly gushing foreword, gags a bit towards the end, and concedes: "Not all arguments here are scrupulous or fair".

In retrospect, the decision to ban the South African scholars is made to appear high-minded and idealistic; motivated by sincere abhorrence for apartheid (which in fact several of the scholars banned also abhor). But the documents contemporary with the relevant transactions, cited by Professor Ucko, reflect a different motivation to that claimed in retrospect. The following extract is from the minutes of the British Executive Committee of 15

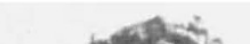




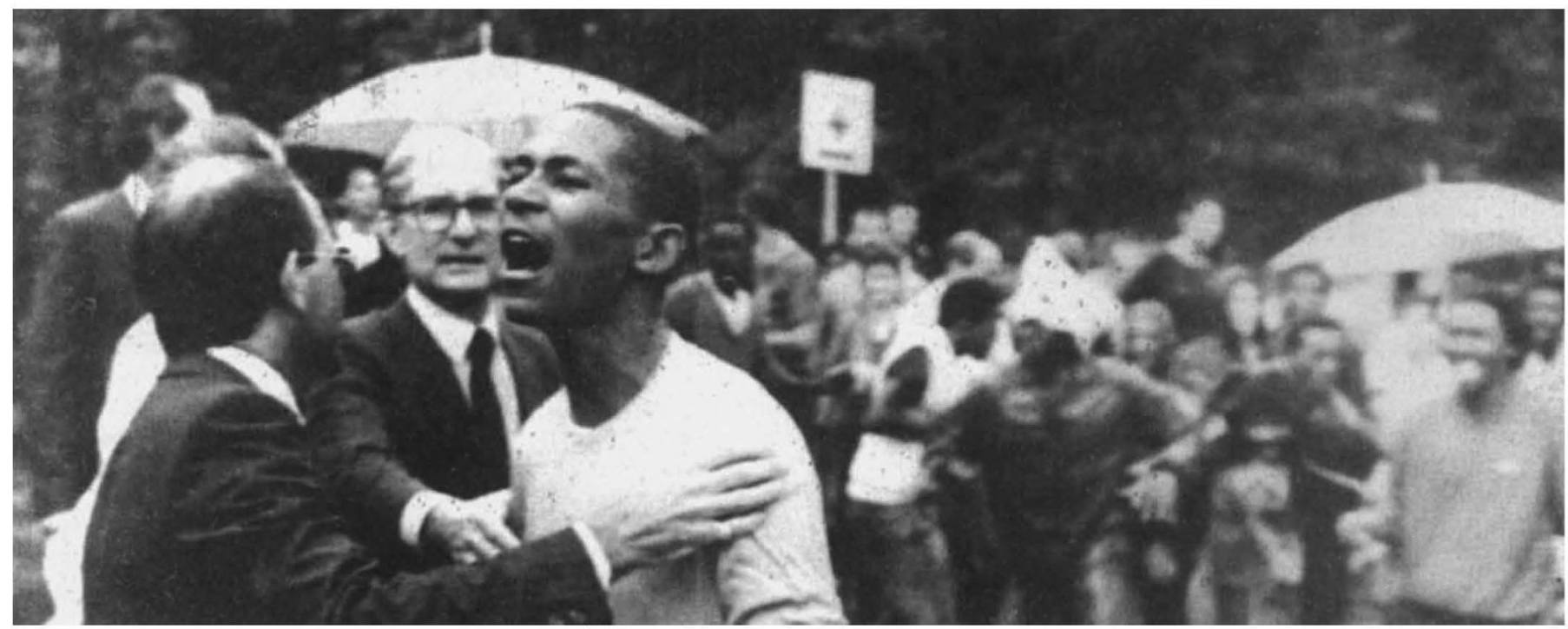

Educated response - unrest in South Africa itself, as students at the University of Witwatersrand commemorate the Sharpeville massacre.

the freedom to publish and to exchange information. If those freedoms are to be dismissed as bourgeois luxuries, as Professor Ucko's rhetoric implies, it seems doubtful whether what remains can reasonably be described as freedom at all.

It is easy to protest one's devotion to freedom-at-large. It may be a little more difficult to defend a particular set of freedoms, in relation to which you have responsibility, when those freedoms come under pressure. Academic freedom may indeed be "a shaky edifice", as Professor Ucko says. But those responsible for "a breach of the principle of free academic exchange" - a breach acknowledged by Professor Ucko himself - hardly have the right to reproach the edifice so breached for its shaky condition.

If it could be demonstrated that restrictions on academic freedom would relieve the oppression of blacks in South Africa, then there would indeed be a case for considering such restrictions. But no such demonstration has been made. As far as Pretoria is concerned, the so-called "academic boycott" is a joke. The South African institutions damaged by the "boycott" - or rather by the outbreaks of student violence organized in the name of the boycott - are the liberal Englishspeaking universities, those which alone take black students in significiant numbers. To suppose that Pretoria feels adversely affected by damage done to those institutions is like supposing that Mrs Thatcher could be brought to her knees by an international boycott of the North London Polytechnic.

Professor Ucko does not attempt to show that the "academic boycott" or the "World Archaeological Congress" has damaged the Pretoria regime, or is capable of damaging it. What he does is to say repeatedly (and quite truly) that the African National Congress, UNESCO, the UN Special Committee on Apartheid and a long et cetera, reaching down to the
Chairman of the Southampton City Council, all demand that South African scholars be kicked out of international scholarly gatherings. That scholars should assert any will or mind of their own in scholarly matters in the presence of such a formidable array of non-scholarly authorities seems incomprehensible to Professor Ucko. He points out, for example that "insistence of South African archaeologists ... to attend international gatherings ... goes directly contrary to the A.N.C. position". That apparently should settle the matter, for any archaeologist worthy of his salt.

The idea of the verdict of an institution as automatically binding on individual intellects, is an old one, but one that seems to be on its way back. For Professor Ucko and his friends, "individualists" are people who have to be made to toe the line, in one way or another. Thus, when the Southampton lobby were trying to swing votes to their side on the eve of a critical IUPPS meeting in Paris, they went to work on (among others) a certain Mexican prehistorian, Professor J. Lorenzo. Mexico - meaning the Mexican government - was sound on the boycott from the lobby's point of view. But might this particular Mexican scholar have the nerve to vote differently from what his government wanted? It seemed he might. "We were worried by reports that Professor Lorenzo was an individualist." The Southampton lobby could not win him round, so they put the pressure on to keep him away from the meeting. "In the event", says Professor Ucko of his Mexican colleague, "he also did not materialize in Paris - maybe he had been convinced by a letter from the A.N.C. or, as a result of a number of telephone calls to the British Ambassador in Mexico, by a word from his Foreign Minister!" (Professor Ucko's exclamation mark). Similar pressure seems to have been applied to an Indian archaeologist whose stance is described as "equivocal".

It is well known that in most Third World countries scholars are, for various reasons, much more vulnerable to governmental pressure than their counterparts in the West. But that Western scholars could deliberately use that vulnerability, in order to force their Third World colleagues into line, through signals to their governments, is something that I would not have believed did I not have Professor Ucko's gleeful testimony to that effect (on p. 95 of this book).

Julian Benda wrote of "the treason of the clerks". He meant by that, not treason to a particular country or ideology, but the betrayal by intellectuals of their actual function. Intellectuals betray their function, in Benda's view, when they subordinate it to the demands of an ideology; when they subordinate individual judgement to the demands of a political collective; and when they seek to coerce other intellectuals into similar patterns of behaviour.

Anyone interested in the state of "the treason of the clerks" in Britain today should read Academic Freedom and Apartheid. And anyone reading it should remember that Professor Ucko is not some lonely, marginal figure. It is not enough to say that the Association of University Teachers are on Professor Ucko's side; the AUT were among the bodies who pushed this particular teacher towards the position which he has now assumed. So, from the Benda point of view - which I share - the rot has gone pretty far in these islands. And if we may judge from the Southampton story, it has gone a lot further in Britain at this time than in the academies of France, Germany or North America.

Conor Cruise O'Brien, Whitewater, Howth Summit, Dublin, Ireland, is Pro-Chancellor of the University of Dublin. He was ViceChancellor of the University of Ghana from 1962 to 1965, and Editor-in-Chief of The Observer newspaper from 1979 to 1981. 